\title{
Evaluation of antioxidant, antibacterial and physicochemical properties of whey protein-based edible films incorporated with different soy sauces
}

\author{
A. García ${ }^{a}$, L.M. Pérez ${ }^{\mathrm{a}, \mathrm{b}}$, G.N. Piccirillii ${ }^{\mathrm{a}, \mathrm{c}}$, R.A. Verdini ${ }^{\mathrm{a}, \mathrm{c}, *}$

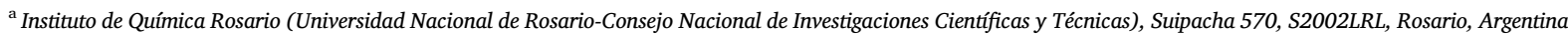 \\ ${ }^{\mathrm{b}}$ Facultad de Química e Ingeniería del Rosario (Pontificia Universidad Católica Argentina- Consejo Nacional de Investigaciones Científicas y Técnicas), Av. Pellegrini 3314, \\ S2002QEN, Rosario, Argentina \\ ' Área Bromatología y Nutrición (Departamento de Ciencias de los Alimentos y del Medio Ambiente), Facultad de Ciencias Bioquímicas y Farmacéuticas, Universidad \\ Nacional de Rosario, Suipacha 531, S2002LRK, Rosario, Argentina
}

\section{A R T I C L E I N F O}

\section{Keywords:}

Whey proteins concentrate

Commercially-available soy sauces

Antimicrobial films

Antioxidant activity

\begin{abstract}
A B S T R A C T
Soy sauce is a traditional seasoning for foods available at the global market that is consumed all over the world. This sauce has a unique flavor and also antimicrobial and antioxidant properties. There is a wide range of soy sauces and their differences are mainly based on the manufacturing methods. Variation in chemical composition is mainly due to differences in fermentation process and the addition of supplementary ingredients like flavor enhancers, among others. The present work, firstly evaluated several physico-chemical parameters of five commercial soy sauces $(\mathrm{pH}$, titratable acidity, acetic acid and potassium sorbate, total solids, total phenol and total carbonyl derivatives). In addition, antimicrobial activity of soy sauces in liquid medium was analyzed against three food-borne bacterial pathogens, namely Escherichia coli, Listeria monocytogenes and Salmonella Typhimurium. Subsequently, whey protein concentrate (WPC)-based edible films were prepared with the addition of soy sauces $(5 \% \mathrm{v} / \mathrm{v})$. Next the films were characterized according to physicochemical properties (thickness, moisture content, solubility in water), optical parameters (transparency, color, Fourier transform infrared spectrum), tensile properties and antioxidant and antimicrobial activities. Our results confirmed that addition of soy sauces not only improved films organoleptic properties but also conferred antioxidant activity and antimicrobial activity on film surface.
\end{abstract}

\section{Introduction}

Food packaging research is receiving a considerable attention due to the development of eco-friendly materials made from natural polymers as an alternative for synthetic plastics. In the last decades, the improvements in edible films technology have turned these biomaterials as an excellent choice for food quality protection, especially for perishable items susceptible to oxidative and microbial deterioration (Otoni et al., 2017). In such sense, edible films have become promising systems to be used as carriers for some active substances such as nutrients, flavoring, antimicrobial and antioxidant agents, thus enhancing safety, nutritional and sensory properties of packaged foods (Lin \& Zhao, 2007; Mellinas et al., 2016; Salgado, Ortiz, Musso, Di Giorgio, \& Mauri, 2015). In particular, the use of by-products derived from agroindustrial processes to manufacture films has received a great deal of attention. In fact, proteins obtained from the cheese making effluents have been extensively reported as raw materials for films formulation.
Whey proteins have proved to be excellent materials for the production of edible films with interesting mechanical and barrier properties, and there are recent studies that reported the inclusion of various antimicrobial agents for prevention of food pathogens growth (Janser Soares de Castro et al., 2017). Among which, can be mentioned the incorporation of eugenol and carvacrol as complexes with cyclodextrin (Barba, Eguinoa, \& Maté, 2015), cinnamon essential oil (Bahram et al., 2014), liquid smoke (Soazo, Pérez, Piccirilli, Delorenzi, \& Verdini, 2016), lysozyme (Boyac1, Korel, \& Yemenicioğlu, 2016) and Lactobacillus sakei cell-free supernatant (Beristain-Bauza, Mani-López, Palou, \& López-Malo, 2017).

Soy sauce is a well-known liquid seasoning currently worldwide used in cooking and is very widespread at the global market (Xu et al., 2013). Its intense umami taste and characteristic aroma have contributed to raising this product consumption (Li et al., 2018). The varieties of soy sauce that are produced depend on the type and ratio of the raw materials used, the microorganisms employed and the

\footnotetext{
* Corresponding author. Instituto de Química Rosario (IQUIR, UNR-CONICET), Facultad de Ciencias Bioquímicas y Farmacéuticas (UNR), Suipacha 570, S2002LRL, Rosario, Santa Fe, Argentina.

E-mail addresses: verdini@iquir-conicet.gov.ar, rverdini@fbioyf.unr.edu.ar (R.A. Verdini).
} 
fermentation conditions, as well as the addition of other ingredients like flavor enhancers (Kamal et al., 2016). In general, this fermented food is derived from soybean or wheat and contains water, salt, peptides, isoflavones, free sugar, and organic acids produced during fermentation.

Soy sauce contains certain bioactive components in addition to its taste components, and various biological activities of soy sauce have been reported such as anti-carcinogenic, antihypertensive, and antimicrobial activity against Shigella flexneri, Salmonella typhi, S. paratyphi, S. enteritidis, Vibrio cholerae, and Escherichia coli 0157:H7 (Kataoka, 2005). Additionally, soy sauce contains a wide range of antioxidant agents, such as phenolic compounds, isoflavones, melanoidins (formed by Maillard reaction during fermentation), free amino acids and superoxide dismutase (Feng et al., 2015; Kim et al., 2013). Thus, soy sauce represents an interesting ingredient for use in active edible films formulation as an attempt to extend shelf-life and add value to the product. Nevertheless, their inclusion in edible films may modify several film physicochemical properties.

It is noteworthy that, in best of our knowledge, there are no reported data about protein based-edible films formulated with the incorporation of soy sauce. Therefore, the aim of the present work was to elaborate edible films made from whey protein concentrate (WPC) with the addition of different commercially available soy sauces and to characterize the structural, optical, physicochemical, antioxidant and microbiological aspects of the obtained films.

\section{Materials and methods}

\subsection{Materials}

Whey protein concentrate (WPC) 80\% (http://pdfood.com.br/Whey \%20Protein\%20-\%201.pdf; Arla Food Ingredients S.A, Martinez, Argentina) and glycerol (Gly) (Cicarelli, San Lorenzo, Argentina) were used to prepare film forming solutions. Five soy sauces (SS) were acquired from different local manufacturers (SS1, SS2, SS3, SS4 and SS5). Mueller-Hinton broth and agar were purchased from Britania (Buenos Aires, Argentina). All other reagents were of analytical grade. The microorganisms used were Escherichia coli O157:H7 strain EDL933 (ATCC 43895) obtained from Área Bacteriología Clínica (Facultad de Ciencias Bioquímicas y Farmacéuticas, Universidad Nacional de Rosario, Argentina), Salmonella Typhimurium (ATCC 14028) provided by Dr. Susana Checa (Instituto de Biología Molecular y Celular de Rosario, IBR-CONICET), and Listeria monocytogenes (ATCC 19115) kindly donated by Dr. Ana Bessone (Laboratorio Americano, Rosario, Argentina).

\subsection{Characterization of soy sauce samples}

\subsubsection{Chemical composition}

Soy sauces were characterized by determination of $\mathrm{pH}$, titratable acidity, total solid content, total phenol derivatives, total carbonyl derivatives and potassium sorbate concentration. A digital $\mathrm{pH}$ meter (Metrohm 713, Metrohm Ltd., Herisau, Switzerland) was used for $\mathrm{pH}$ measurement. Samples were diluted in distilled water for titration with $0.1 \mathrm{~N} \mathrm{NaOH}$ ( $\mathrm{pH}$ value of 8.3 was taken as the end point) and titratable acidity was calculated as \% acetic acid (AOAC, 2012). For total solids content determination, samples were dried to constant weight at $105^{\circ} \mathrm{C}$. Results were expressed as percentage of the liquid sample. To estimate total phenol derivatives a modification of the Folin Ciocalteu method was used (Chun et al., 2005). Results were expressed as $\mu \mathrm{g} \cdot \mathrm{mL}^{-1}$ of gallic acid equivalent (GAE). To determine carbonyl derivatives 2,4-dinitrophenylhydrazine was used (ASTM, 2000). Results were expressed as $\mu \mathrm{g} . \mathrm{mL}^{-1}$ of carbonyl. Potassium sorbate concentration was determined by means of high performance liquid chromatography (HPLC). The determination was carried out using a C18 column, $(25 \mathrm{~cm} \times 4.6 \mathrm{~cm}, 5 \mu \mathrm{m}$, Supelco, PA, USA) and an UV/VIS detector (Gilson 151, Gilson, WI, USA). The mobile phase was consisted of a solution of sodium acetate $(\mathrm{pH} 4.2)$ /acetonitrile at a ratio of $80: 20$ (under isocratic elution), the flow rate was $1 \mathrm{~mL} / \mathrm{min}$ and the detection wavelength was $230 \mathrm{~nm}$ (Soazo et al., 2016). Results were expressed as $\%$ of potassium sorbate. All assays in this section were carried out in triplicate $(n=3)$.

\subsubsection{Antioxidant activity of soy sauces}

Antioxidant activity of soy sauces was analyzed with the ABTS method. A solution $7 \mathrm{mM}$ of 2,2'-Azino-bis(3-ethylbenzothiazoline-6sulfonic acid) diammonium salt (ABTS) was mixed with a potassium persulfate $(2.45 \mathrm{mM})$ solution and left to react in darkness for at least $16 \mathrm{~h}$ to form the ABTS radical (ABTS. ${ }^{+}$). This stock solution was diluted with a mixture of ethanol:water (50:50) to achieve an absorbance of $0.70 \pm 0.02$ at $\quad 730 \mathrm{~nm}$. A $( \pm)$-6-Hydroxy-2,5,7,8-tetramethylchromane-2-carboxylic acid (Trolox) solutions were used to perform the calibration curve $(0.04-0.30 \mathrm{mM})$. For this purpose, $60 \mu \mathrm{L}$ of sample were mixed with $840 \mu \mathrm{L}$ of diluted $\mathrm{ABTS}^{+}{ }^{+}$solution and place in a $37^{\circ} \mathrm{C}$ water bath for $20 \mathrm{~min}$. After that, the spectrophotometric determinations were carried out at $730 \mathrm{~nm}$. The results were expressed as $\mu$ mol equivalents of Trolox per $\mathrm{mL}$ of sample (Rufián-Henares, Guerra-Hernández, \& García-Villanova, 2013). Taking into account that the $\mathrm{pH}$ of films containing SS was adjusted to 5.5, antioxidant activity of soy sauces was also measured at this $\mathrm{pH}$ (Pérez, Soazo, Balagué, Rubiolo, \& Verdini, 2014). This analysis was made in triplicate $(n=3)$.

\subsubsection{Inhibitory activity of soy sauces in liquid media}

The effect of the soy sauces over the bacterial growth in a liquid medium was evaluated by assessing the minimum inhibitory concentration (MIC) against Escherichia coli O157:H7 strain EDL933 (ATCC 43895), Salmonella Typhimurium (ATCC 14028), and Listeria monocytogenes (ATCC 19115). The MIC was estimated as described by (Pérez et al., 2014) following the recommendations of the National Committee for Clinical Laboratory Standards for the macrodilution broth method. For this purpose, a 16-18 h culture of each bacterial strain in MuellerHinton broth $(\mathrm{pH}=6.8)$ was adjusted to McFarland 0.5 standard in saline solution (approximately $1.5 \times 10^{8} \mathrm{CFU} / \mathrm{mL}$ ). Then, a $1 / 150$ dilution in saline solution was used as the test inoculum for the MIC test. One $\mathrm{mL}$ of the bacterial inoculum was added and mixed with $1 \mathrm{~mL}$ of each soy sauce solution in Mueller-Hinton broth. The assay was carried out at two different $\mathrm{pH}$ of the broth medium (5.5 and 6.8) to evaluate the influence of ionization over antimicrobial activity. The soy sauce concentrations studied were $1.25,2.5,5.0$, and $10 \%(\mathrm{v} / \mathrm{v})$. All tubes were incubated for $48 \mathrm{~h}$ at $37^{\circ} \mathrm{C}$. The MIC values were visually detected as the lowest concentration of soy sauce that completely inhibits bacterial growth (i.e., no turbidity observed after incubation). To discard possible contaminations a tube containing only broth medium was evaluated. Additionally, a control tube without soy sauce was inoculated to test microbial growth. Both control tubes were also used to assess the MIC endpoints.

Minimum bactericide concentration (MBC) was estimated by spreading $100 \mu \mathrm{L}$ of solution from the negative tubes (i.e., showing no turbidity in the MIC determination) over Mueller-Hinton agar plates (pH 6.8) and incubated at $37^{\circ} \mathrm{C}$ for $48 \mathrm{~h}$. The MBC was determined from the inoculated plates that showed less than ten colonies growth $(0.1 \%$ of the initial inoculum).

\subsection{Film preparation}

Films were prepared according to Soazo et al. (2016), with minor modifications. Briefly, WPC $(10 \mathrm{~g})$ was dispersed in water $(100 \mathrm{~mL})$ and $5 \mathrm{~g}$ of glycerol (as plasticizer) were added to the film-forming solution. Then, the dispersion was heated at $90^{\circ} \mathrm{C}$ for $30 \mathrm{~min}$ in a water bath (TDS-40, Tecno Dalvo, Santa Fe, Argentina), homogenized (5 min; 20,000 rpm) with an Omni GLH homogenizer (Omni International Inc., Kennesaw, USA), and finally degassed by sonication (Cole-Parmer 8890E-MT, Cole-Parmer, Buenos Aires, Argentina) for $60 \mathrm{~min}$. After that, the solution was cooled at room temperature (to prevent further 
denaturation of the whey proteins) in an ice bath and then different SS were added at $5 \%(\mathrm{v} / \mathrm{v})$. Control films without SS were also prepared. The $\mathrm{pH}$ of each film-forming solution was adjusted to 5.5. Petri dishes were filled with $10 \mathrm{~g}$ of film-forming solution and dried on a leveled surface in an environmental chamber (SCT Pharma, Temperley, Argentina) for $18 \mathrm{~h}$ at $30{ }^{\circ} \mathrm{C}$ and $50 \%$ relative humidity. After that, the plates were placed on an oven (Dalvo Instruments, Santa Fe, Argentina) at $35^{\circ} \mathrm{C}$ for $3 \mathrm{~h}$. The films were removed from the plates and were stabilized for $24 \mathrm{~h}$ at $25^{\circ} \mathrm{C}$ and $58 \%$ relative humidity.

\subsection{Physicochemical properties of films}

\subsubsection{Film thickness}

An electronic digital disk micrometer (Schwyz ${ }^{\circledast}$, China) was used to measure the thicknesses of five replicates of each film formulation at nine locations on the films (Soazo et al., 2016).

\subsubsection{Moisture content and solubility in water}

Determination of moisture content was carried out using a shallow weighing bottle that has been previously dried in an oven (Dalvo Instruments, Santa $\mathrm{Fe}$, Argentina) at $105^{\circ} \mathrm{C}$ and cooled to room temperature in a desiccator. Films were cut into pieces of $15 \times 7.5 \mathrm{~mm}$, placed on the weighing bottle and dried at $105^{\circ} \mathrm{C}$ to constant weight. Moisture content was determined as a fraction of the initial film weight lost during drying and reported on a wet basis, according to Pérez, Piccirilli, Delorenzi, and Verdini (2016).

For solubility analysis, a film section $(15 \times 7.5 \mathrm{~mm})$ was put in a test tube (pre-dried), weighted, dried in the oven for $24 \mathrm{~h}$ at $70^{\circ} \mathrm{C}$, cooled in the desiccator and weighted again to obtain initial dry matter. After that, $10 \mathrm{~mL}$ of distilled water were added and the tubes were shaken for $24 \mathrm{~h}$ at $50 \mathrm{rpm}$ and $25^{\circ} \mathrm{C}$ in an elliptical shaker (Vicking, Buenos Aires, Argentina). A filter paper was weighted, used to retain the solids in the sample, dried in an oven for $24 \mathrm{~h}$ at $70^{\circ} \mathrm{C}$ and weighted to obtain the not solubilized dry matter. Solubility in water was calculated by subtracting the weight of dry matter not solubilized from the weight of initial dry matter and expressed as soluble solids (\%) (Soazo, Rubiolo, \& Verdini, 2011). Analysis was performed in quintuplicate $(n=5)$.

\subsubsection{Optical properties}

2.4.3.1. Color analysis. Pictures were taken using a digital camera (Canon Eos Rebel T3, Taiwan) to carry out color analysis. For this purpose, films were cut into rectangular pieces of $10 \mathrm{~mm} \times 30 \mathrm{~mm}$, placed on a wooden box, and photographed over a matte white background. Camera was set as follow: manual mode with lens aperture at $\mathrm{f}=8$, time of exposition $1 / 50$, no flash, ISO sensibility 400 , maximum resolution, and storage mode in RAW format. Samples were illuminated using 4 fluorescent lamps (Osram, Biolux, Natural Daylight, 18 W/965, München, Germany) with a color temperature of $6500 \mathrm{~K}$ (D65, standard light source commonly used in food research) and a color-rendering index Ra of 95\%. Uniform illumination system was provided by electronic ballast and an acrylic light diffuser (Soazo, Pérez, Rubiolo, \& Verdini, 2015). International Color Consortium (ICC) profile and Photoshop ${ }^{\circledR}$ (Adobe Systems Inc., Mountain View, USA) were used to process the images to obtain $L^{*}, a^{*}$, and $b^{*}$ parameters average values (considering the whole sample) as described by Soazo et al. (2015). Determinations were performed in quintuplicate $(n=5)$.

2.4.3.2. Transparency. A spectrophotometer was used to measure the visible light barrier properties on films. Films were cut into rectangular pieces $(10 \mathrm{~mm} \times 30 \mathrm{~mm})$ and placed on internal side of a spectrophotometer cell. The analysis was carried out at $600 \mathrm{~nm}$. The transparency was calculated as follows (Ramos et al., 2013).

Transparency $=\mathrm{A}_{600} / \mathrm{X}$ where $A_{600}$ is the absorbance at $600 \mathrm{~nm}$ and $X$ the film thickness (mm). Analyses were performed in quintuplicate $(n=5)$.

\subsubsection{Tensile properties}

Tensile tests were performed to evaluate the mechanical strength of the films using a Multi Test 2.5-D motorised test frame (Mecmesin, VA, USA) equipped with a $25 \mathrm{~N}$ digital force gauge. Samples were prepared by cutting films into strips $(60 \mathrm{~mm} \times 7 \mathrm{~mm})$ using a scalpel. The strip ends were fixed with double sided tape and squares of $30 \mathrm{~mm}$ of cardstock to prevent tearing and slippage in the testing device (Pérez et al., 2016). The exposed film strip length, as well as the initial grip distance, was $30 \mathrm{~mm}$. Samples prepared as explained previously, were stabilized for $24 \mathrm{~h}$ at $25^{\circ} \mathrm{C}$ and $58 \%$ relative humidity before analysis. Crosshead speed was $0.05 \mathrm{~mm} / \mathrm{s}$. Tensile test was carried out to obtain tensile strength (TS) and elongation (E). To calculate TS, the peak load was divided by the cross-sectional area of the initial film (thickness of film $\times 7 \mathrm{~mm}$ ) and $\mathrm{E}$ was obtained as the percentile of the change in the length of specimen to the original distance between the grips (Soazo, Pérez, Rubiolo, \& Verdini, 2013). Five replications were performed $(n=5)$.

\subsubsection{FTIR-ATR analysis}

Fourier transform infrared (FTIR) spectra were obtained by a FTIRPrestige-21 (Shimadzu, Tokyo, Japan) with Attenuated Total Reflectance (ATR) attachment. Scanning range was $650-4000 \mathrm{~cm}^{-1}$ with a resolution of $4 \mathrm{~cm}^{-1}$. Each sample was analyzed by triplicate performing 20 scans.

\subsubsection{Antioxidant activity of films}

A portion of film $(0,100 \mathrm{~g})$ was placed in water, sonicated for $1 \mathrm{~h}$, centrifuged, and the supernatant was submitted to the analysis of antioxidant activity as described in section 2.2.2.

\subsubsection{Inhibition zone assay in agar media}

Films antimicrobial activity was evaluated by the inhibition zone assay as described by Pérez et al. (2014). Briefly, WPC-based edible films incorporated with SS were cut in $12 \mathrm{~mm}$ diameter discs with a sterile cork borer. Petri dishes containing $20 \mathrm{~mL}$ of Mueller Hinton agar (pH 5.5) were seeded with a suspension of the testing microorganisms adjusted to the 0.5 McFarland standard in saline solution. Films discs were aseptically transferred to the inoculated plates and incubated at $37^{\circ} \mathrm{C}$ for $24 \mathrm{~h}$. The diameter of the inhibition zone (i.e., the clear area of non-growth around the film disc) was measured using a caliber. WPCbased films without the addition of SS were used as negative controls. Experiments were performed in triplicate $(n=3)$.

\subsection{Statistical analysis}

Linear correlation tests and analysis of variance (ANOVA) coupled with Turkey's test were performed using the statistical programme GraphPad Prism version 5.00 for Windows (GraphPad Software, San Diego, CA, USA, www.graphpad.com). The significance level was set at $p<0.05$.

\section{Results and discussion}

\subsection{Characterization of soy sauce samples}

\subsubsection{Chemical composition}

Data pertaining to the chemical characterization of the different SS are shown in Table 1 . SS presented $\mathrm{pH}$ values that ranged between $3.90 \pm 0.02$ and $4.53 \pm 0.01$. This range is in agreement with values reported by Syifaa, Jinap, Sanny, and Khatib (2016) between 4.01 and 4.88. Particularly, SS3 showed significant differences when compared to the others SS, exhibiting a higher $\mathrm{pH}$ value. SS differed significantly in the titratable acidity, ranging from $0.32 \pm 0.01$ to $1.01 \pm 0.02 \%$ of 
Table 1

Chemical characterization of five commercial soy sauces (SS).

\begin{tabular}{|c|c|c|c|c|c|}
\hline & SS1 & SS2 & SS3 & SS4 & SS5 \\
\hline $\mathrm{pH}$ & $4.07 \pm 0.05^{\mathrm{b}}$ & $3.90 \pm 0.02^{\mathrm{a}}$ & $4.53 \pm 0.01^{\mathrm{c}}$ & $4.07 \pm 0.02^{b}$ & $4.01 \pm 0.02^{b}$ \\
\hline Titratable acidity (\% acetic acid) & $0.36 \pm 0.01^{\mathrm{b}}$ & $0.69 \pm 0.01^{\mathrm{d}}$ & $0.32 \pm 0.01^{\mathrm{a}}$ & $0.44 \pm 0.01^{\mathrm{c}}$ & $1.01 \pm 0.02^{\mathrm{e}}$ \\
\hline Total solid content $(\% \mathrm{w} / \mathrm{w})$ & $16.51 \pm 0.06^{\mathrm{c}}$ & $17.36 \pm 0.01^{\mathrm{d}}$ & $19.95 \pm 0.08^{\mathrm{e}}$ & $15.56 \pm 0.08^{\mathrm{b}}$ & $8.70 \pm 0.02^{\mathrm{a}}$ \\
\hline Total phenol derivatives ( $\mu$ g. $\mathrm{mL}^{-1} \mathrm{GAE}$ ) & $992 \pm 18^{\mathrm{a}, \mathrm{b}}$ & $1409 \pm 85^{\mathrm{d}}$ & $1180 \pm 59^{c}$ & $882 \pm 18^{\mathrm{a}}$ & $1051 \pm 69^{\mathrm{b}, \mathrm{c}}$ \\
\hline Total carbonyl derivatives $\left(\mu \mathrm{g} \cdot \mathrm{mL}^{-1}\right)$ & $1302 \pm 39^{c}$ & $730 \pm 13^{\mathrm{a}}$ & $1278 \pm 56^{c}$ & $1018 \pm 11^{\mathrm{b}}$ & $1405 \pm 114^{\mathrm{c}}$ \\
\hline Potassium sorbate $(\%)$ & $0.098 \pm 0.008^{\mathrm{b}}$ & $0.078 \pm 0.007^{\mathrm{a}}$ & $0.096 \pm 0.007^{\mathrm{b}}$ & $0.093 \pm 0.006^{\mathrm{a}, \mathrm{b}}$ & $0.086 \pm 0.004^{\mathrm{a}, \mathrm{b}}$ \\
\hline $\begin{array}{l}\text { TEAC (native } \mathrm{pH}) \\
\qquad\left(\mu \mathrm{mol} \cdot \mathrm{mL}^{-1}\right)\end{array}$ & $6.3 \pm 0.2^{\mathrm{a}, \mathrm{A}}$ & $7.7 \pm 0.3^{\mathrm{b}, \mathrm{A}}$ & $8.8 \pm 0.6^{\mathrm{b}, \mathrm{A}}$ & $6.2 \pm 0.6^{\mathrm{a}, \mathrm{A}}$ & $6.1 \pm 0.4^{\mathrm{a}, \mathrm{A}}$ \\
\hline $\begin{array}{r}\text { TEAC }(\mathrm{pH}=5.5) \\
\left(\mu \mathrm{mol} . \mathrm{mL}^{-1}\right)\end{array}$ & $10.4 \pm 0.1^{\mathrm{a}, \mathrm{B}}$ & $15.4 \pm 0.8^{\mathrm{c}, \mathrm{B}}$ & $12.7 \pm 0.1^{\mathrm{b}, \mathrm{B}}$ & $12.1 \pm 0.5^{\mathrm{b}, \mathrm{B}}$ & $15.2 \pm 0.2^{\mathrm{c}, \mathrm{B}}$ \\
\hline
\end{tabular}

Data corresponds to mean values and standard deviations of five samples.

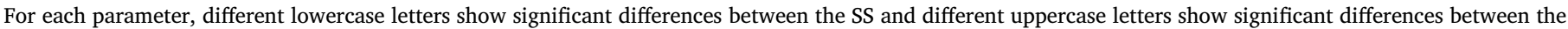
same SS at different $\mathrm{pH}$ value $(\mathrm{p}<0.05)$.

GAE: Gallic acid equivalent.

TEAC: Trolox equivalent antioxidant capacity.

acetic acid, following the decreasing order: SS5, SS2, SS4, SS1 and SS3 (Table 1). However, SS3 that showed the higher $\mathrm{pH}$ value had the lower value of titratable acidity in agreement with Cho, Zhao, Kim, Kim, and Chung (2018). Besides, SS5 presented the higher value of titratable acidity but the $\mathrm{pH}$ value was only statistically different from SS3. The aforementioned results can be explained taking into account that $\mathrm{pH}$ is a measure of proton concentration and not of total concentration of acids. A weak acid presents in solution a substantial proportion of undissociated form and thus does not contribute directly to the $\mathrm{pH}$ value, whereas less weak acids can develop higher $\mathrm{pH}$ and low titratable acidity values.

Concerning total solids content, all SS presented statistical differences between them that may be related to salt $(\mathrm{NaCl})$ content and peptide/amino acids composition due to differences in the methods of manufacture (i.e., fermentation or acid-hydrolysis). Total solids content contribute to the body of soy sauce. SS2 presented the highest value of total phenol derivatives whereas the lowest values were observed in SS1 and SS4. Total carbonyl derivatives were also variable, sauces SS1, SS3 and SS5 exhibited the highest values and SS2 the lowest. As expected, potassium sorbate content in all sauces was lower than the limit of $0.1 \%$ established by the Argentine Food Code (Código Alimentario Argentino, 2018).

As we have already mentioned, soy sauces may differ on the type and the ratio of the raw materials used on its formulation, as well as in the manufacturing methods, the fermentation conditions and the microorganisms used in its production. Moreover, the addition of some other ingredients like flavours, aroma enhancers, preservatives and colourings agents will affect the chemical composition of the final product and, as a consequence, soy sauces biological properties.

\subsubsection{Antioxidant activity of soy sauces}

Antioxidant activity of different SS is shown in Table 1. Soy sauces presented an antioxidant activity ranged between $6.1 \pm 0.4$ and $8.8 \pm 0.6 \mu \mathrm{mol}$ of Trolox $/ \mathrm{mL}$ of sample obtained with the ABTS method. SS2 and SS3 presented the highest values, while SS1, SS4 and SS5 were the lowest. Taking into account that films were prepared by adjusting the $\mathrm{pH}$ of the film-forming solutions to a final value of 5.5, the same assay was carried out at the more acidic $\mathrm{pH}$. In this case, radical scavenging capacity of all SS significantly increases with decreasing $\mathrm{pH}$ of the medium $(p<0.05)$, but the magnitude of this change was different for each SS. At a pH value equal to 5.5, SS5 and SS2 exhibited the greatest antioxidant activities, whereas SS1, SS3 and SS4 presented the lowest values. A positive correlation between the total phenol derivatives and antioxidant activity mainly at $\mathrm{pH} 5.5$ was found, these results could indicate that the aforementioned compounds would be the major responsible of the increase in antioxidant activity with $\mathrm{pH}$ decrease. These compounds have the ability to donate hydrogen or electrons beyond their capacity to form stable radical intermediates. Therefore, there should be a close correlation between the content of phenolic compounds and antioxidant activity (Wang, Huang, Venkitasamy, Chai, \& Pan, 2016). Effect of $\mathrm{pH}$ on antioxidant activity of SS could be explained through phenolic compounds redox properties. The oxidation potentials of phenolic compounds decrease with $\mathrm{pH}$, so the antioxidant activity increases (Bayliak, Burdyliuk, \& Lushchak, 2016). Additionally, soy sauces may contain other antioxidant agents such as isoflavones, melanoidins (formed by Maillard reaction during fermentation), free amino acids and superoxide dismutase (Feng et al., 2015; Kim et al., 2013).

\subsubsection{Antimicrobial activity of soy sauces in liquid media}

Antimicrobial activity of SS in liquid media is shown in Table 2. Our results revealed that most SS presented growth inhibitory activity against L. monocytogenes at $\mathrm{pH} 5.5$, except for sample SS3. This sauce showed no antimicrobial activity against none of the food-pathogens evaluated, independently of the $\mathrm{pH}$ of the broth media. Only sample SS5 presented bactericide activity against $L$. monocytogenes at $\mathrm{pH} 6.8$, while at $\mathrm{pH} 5.5$ it was bactericide for this microorganisms and S. Typhimurium; and bacteriostatic for all microorganisms assayed. Variation in the antibacterial activity with $\mathrm{pH}$ may be related to SS composition and the presence of organic acids or other compounds that increase their activity in the non-ionized state. It is known that the unprotonated/protonated ratio of organic acids is relevant for the antimicrobial activity of such compounds because the increased capability of the un-dissociated form to penetrate the plasmatic membrane of the microorganisms (Lück \& Jager, 1997). At this point, it is important to mention that potassium sorbate concentration in all the SS studied (Table 1) was below the MIC value of sorbate for the three microorganisms evaluated, as it was reported in a previous work from our group (Bessone, 2015).

\subsection{Characterization of films}

\subsubsection{Moisture content, solubility in water and film thickness}

Thickness, moisture content, and solubility in water of films are shown in Table 3. Moisture content was higher for films formulated with SS than control films. This fact may be related with the presence of hygroscopic components in the SS such as low molecular weight sugars and organic acids (Hamano, 1994). In addition, a positive correlation was observed between moisture content and films thickness. In particular, WPC-based films incorporated with SS5 that exhibited the lowest moisture content, do not showed significant difference in thickness with respect to control films. Additionally, SS5 presented the lowest total solid content in comparison to the other SSs (Table 1), as it was discussed in section 3.1.1. So, this feature could be associated with the 
capacity of the edible films formulated with SS5 to retain less water. Simultaneously, films incorporated with SS1, SS3 or SS4 exhibited a higher solubility than control films. In a similar way as rationalized for the moisture content, these results could be associated to a higher content of hygroscopic substances in such SS, and related with the total solids content.

\subsubsection{Color analysis and transparency}

Photographs of WPC-based films strips are shown in Fig. 1. Color parameters $L^{*}$ (lightness), $a^{*}$ (red-green hue) and $b^{*}$ (yellow-blue shade), and films transparency are shown in Table 3. Higher $a^{*}$ and $b^{*}$ values were observed in WPC-based film incorporated with SS comparing to control films, indicating an increase in yellowness and redness of that films. The parameter $L^{*}$ was also affected by the incorporation of SS, showing lower values than control films. The films formulated with SS5 exhibited higher values for this parameter than the others SS films, indicating a lower darkening respect to control films. The aforementioned observations reflect the fact that WPC-based films became darker when SS was added in the film formulation. These changes were expected due to the typical brown colour of SS. Product appeal and consumer acceptability are directly influenced by color attributes. It could be seen that the slightly yellowish colour of WPC-based films changed to brown with the addition of SS at edible films formulation. For practical uses, the incorporation of colouring agents may be a benefit in order to overcome undesirable colour of a biopolymers film.

Despite of the changes exhibited in the color parameters between control films and that incorporated with SS, no statistical differences were observed in their transparency. Light transmission is an attribute of fundamental importance for protein-based edible films and is greatly affected by several factors including plasticizer addition, thermal treatment, fabrication process, and storage conditions (Soazo et al., 2016). The fact that all film-forming solutions were adjusted at $\mathrm{pH} 5.5$ could have contributed to homogenize films transparency. As reported in a previous work of our group, $\mathrm{pH}$ affects WPC-based films transparency due to the precipitation of whey proteins near to its isoelectric point (pI 5.0) (Pérez et al., 2014).

\subsubsection{Tensile properties}

Table 3 shows the elongation at break (E) and tensile strength (TS) obtained for WPC films formulated with the addition of SS. It can be observed a tendency to increase in the $\mathrm{E}$ values for the films incorporated with SS, in particular for SS1 and SS5. Otherwise, TS only showed differences in films incorporated with SS5 (higher value) and SS3 (lower value). Hence, films incorporated with SS5 were stronger than the other films due to their higher mechanical resistance (i.e., higher TS). These films were also more flexible than control films owing to their higher extensibility (i.e, higher E). This fact may be related with the presence of small organic acids molecules at SS5 that besides provide acidity (SS5 showed the higher titratable acidity, see Table 1) can acts as plasticizer for WPC-based films, leading to a decrease in the intermolecular forces along the protein chain thus improving films flexibility (Hernandez-Izquierdo \& Krochta, 2008). In general, the results aforementioned suggest different interactions between the protein backbone of the WPC-based film and carbonyl and/or phenolic compounds present in the SS. Several authors reported the occurrence of intermolecular hydrogen bonding between the $\mathrm{N}$-terminal protein end and the hydroxyl group (-OH) of the aromatic hydrocarbon in edible films containing polyphenols (Chaturvedula \& Prakash, 2011; Soazo et al., 2016; Sun, Wang, Kadouh, \& Zhou, 2014).

\subsubsection{FTIR-ATR analysis}

FTIR spectra of WPC-based films formulated with the addition of SS are shown in Fig. 2. There have been several approaches about the whey protein conformational changes caused by different factors like $\mathrm{pH}$, heat, interactions with other molecules, among others (Hemar, Law, Horne, \& Leaver, 2000; Ramos et al., 2013; Wijayanti, Bansal, \& 
Table 3

Physicochemical properties and antioxidant activity of WPC-based edible films obtained with different soy sauces.

\begin{tabular}{|c|c|c|c|c|c|c|}
\hline & Control & SS1 & SS2 & SS3 & SS4 & SS5 \\
\hline Thickness (mm) & $0.183 \pm 0.004^{\mathrm{a}}$ & $0.196 \pm 0.004^{\mathrm{b}, \mathrm{c}}$ & $0.188 \pm 0.006^{\mathrm{a}, \mathrm{b}}$ & $0.207 \pm 0.009^{c}$ & $0.199 \pm 0.007^{\mathrm{b}, \mathrm{c}}$ & $0.180 \pm 0.006^{\mathrm{a}}$ \\
\hline Moisture content (\%) & $13.3 \pm 0.6^{\mathrm{a}}$ & $17.4 \pm 0.6^{\mathrm{c}, \mathrm{d}}$ & $16.5 \pm 0.4^{\mathrm{c}}$ & $17.6 \pm 0.7^{\mathrm{d}}$ & $18.2 \pm 0.6^{\mathrm{d}}$ & $15.0 \pm 0.3^{\mathrm{b}}$ \\
\hline Solubility (\%) & $40 \pm 3^{\mathrm{a}}$ & $48 \pm 2^{\mathrm{b}}$ & $44 \pm 5^{\mathrm{a}, \mathrm{b}}$ & $50 \pm 1^{b}$ & $48 \pm 2^{\mathrm{b}}$ & $42 \pm 1^{\mathrm{a}}$ \\
\hline$a^{*}$ & $6.1 \pm 0.8^{\mathrm{a}}$ & $12.4 \pm 0.6^{\mathrm{b}, \mathrm{c}}$ & $12.6 \pm 0.7^{\mathrm{c}}$ & $14.3 \pm 0.7^{\mathrm{d}}$ & $10.8 \pm 0.6^{b}$ & $11.6 \pm 0.8^{\mathrm{b}, \mathrm{c}}$ \\
\hline$b^{*}$ & $17 \pm 2^{\mathrm{a}}$ & $41 \pm 1^{c}$ & $37 \pm 2^{\mathrm{b}}$ & $42 \pm 1^{\mathrm{c}}$ & $38 \pm 1^{\mathrm{b}}$ & $35 \pm 2^{\mathrm{b}}$ \\
\hline$L^{*}$ & $77.3 \pm 0.7^{\mathrm{e}}$ & $59.2 \pm 0.7^{\mathrm{b}}$ & $65.4 \pm 0.9^{c}$ & $56 \pm 2^{\mathrm{a}}$ & $60.9 \pm 0.6^{\mathrm{b}}$ & $68.5 \pm 0.9^{\mathrm{d}}$ \\
\hline Transparency $(600 \mathrm{~nm})$ & $3.7 \pm 0.3^{\mathrm{a}}$ & $4.2 \pm 0.2^{\mathrm{a}}$ & $4.1 \pm 0.3^{\mathrm{a}}$ & $4.3 \pm 0.6^{\mathrm{a}}$ & $4.3 \pm 0.5^{\mathrm{a}}$ & $4.0 \pm 0.3^{\mathrm{a}}$ \\
\hline E (\%) & $2.3 \pm 0.6^{\mathrm{a}}$ & $7.3 \pm 0.5^{c}$ & $4.1 \pm 0.2^{\mathrm{a}, \mathrm{b}}$ & $4.2 \pm 0.2^{\mathrm{a}, \mathrm{b}}$ & $5.5 \pm 0.1^{\mathrm{a}, \mathrm{b}, \mathrm{c}}$ & $6.0 \pm 0.1^{\mathrm{b}, \mathrm{c}}$ \\
\hline TS (Mpa) & $0.7 \pm 0.2^{\mathrm{b}}$ & $0.6 \pm 0.1^{\mathrm{b}}$ & $0.6 \pm 0.2^{\mathrm{b}}$ & $0.3 \pm 0.1^{\mathrm{a}}$ & $0.5 \pm 0.1^{\mathrm{a}, \mathrm{b}}$ & $1.0 \pm 0.2^{\mathrm{c}}$ \\
\hline TEAC $\left(\mu \mathrm{mol} . \mathrm{g}^{-1}\right)$ & $12.2 \pm 0.7^{\mathrm{a}}$ & $12.5 \pm 0.9^{\mathrm{a}}$ & $13.2 \pm 0.8^{\mathrm{a}}$ & $12.3 \pm 0.6^{\mathrm{a}}$ & $12.1 \pm 0.5^{\mathrm{a}}$ & $15.0 \pm 0.4^{\mathrm{b}}$ \\
\hline
\end{tabular}

Values with different letters in each row are significantly different $(\mathrm{p}<0.05)$.

TS: tensile strength; E: elongation.

TEAC: Trolox equivalent antioxidant capacity.

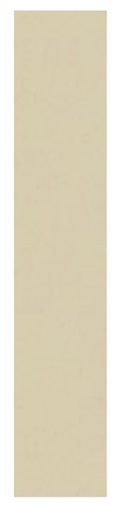

Control

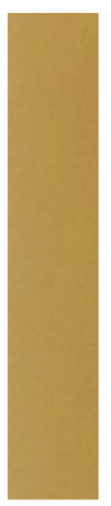

SS1

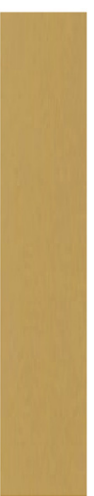

SS2

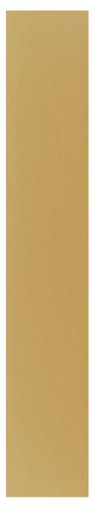

SS3

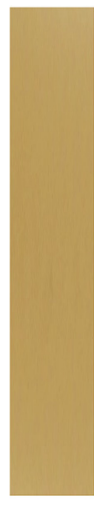

SS4

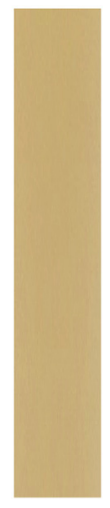

SS5

Fig. 1. Photographs of WPC-based films strips (control: correspond to films without SS; SS1, SS2, SS3, SS4 and SS5: correspond to films incorporated with different SS).

Deeth, 2014). The absorption peaks located in the spectral range $800-1150 \mathrm{~cm}^{-1}$ are attributed to absorption bands of glycerol. The bands located at $3000-3600 \mathrm{~cm}^{-1}$ correspond to free and bound $-\mathrm{OH}$ and $-\mathrm{NH}$ groups. The width of the aforementioned band has been associated with the degree of cross-linking of the protein network and, as a consequence, with the moisture content of WPC-based edible films (Ramos et al. 2013). This fact can be rationalized on the availability of free-OH groups susceptible to interact with water molecules, resulting in the grade of hydration of the film (Jiang, Li, Chai, \& Leng, 2010). The statement above it is also consistent with the data discussed in Table 3. Besides the hygroscopic behaviour of the SS already discussed, the presence of organic molecules in such sauces able to react with whey proteins through covalent bonds may interfere with the hydrogen bonds established at the film protein matrix. Therefore, it is expected that amino or hydroxyl groups of non-crosslinked proteins can form hydrogen bonds with water molecules, thus turning films incorporated with SS to be more susceptible to hydration.

The absorbance in amide I band region $\left(1600-1700 \mathrm{~cm}^{-1}\right)$ is predominantly governed by stretching vibration of the carbonyl peptide

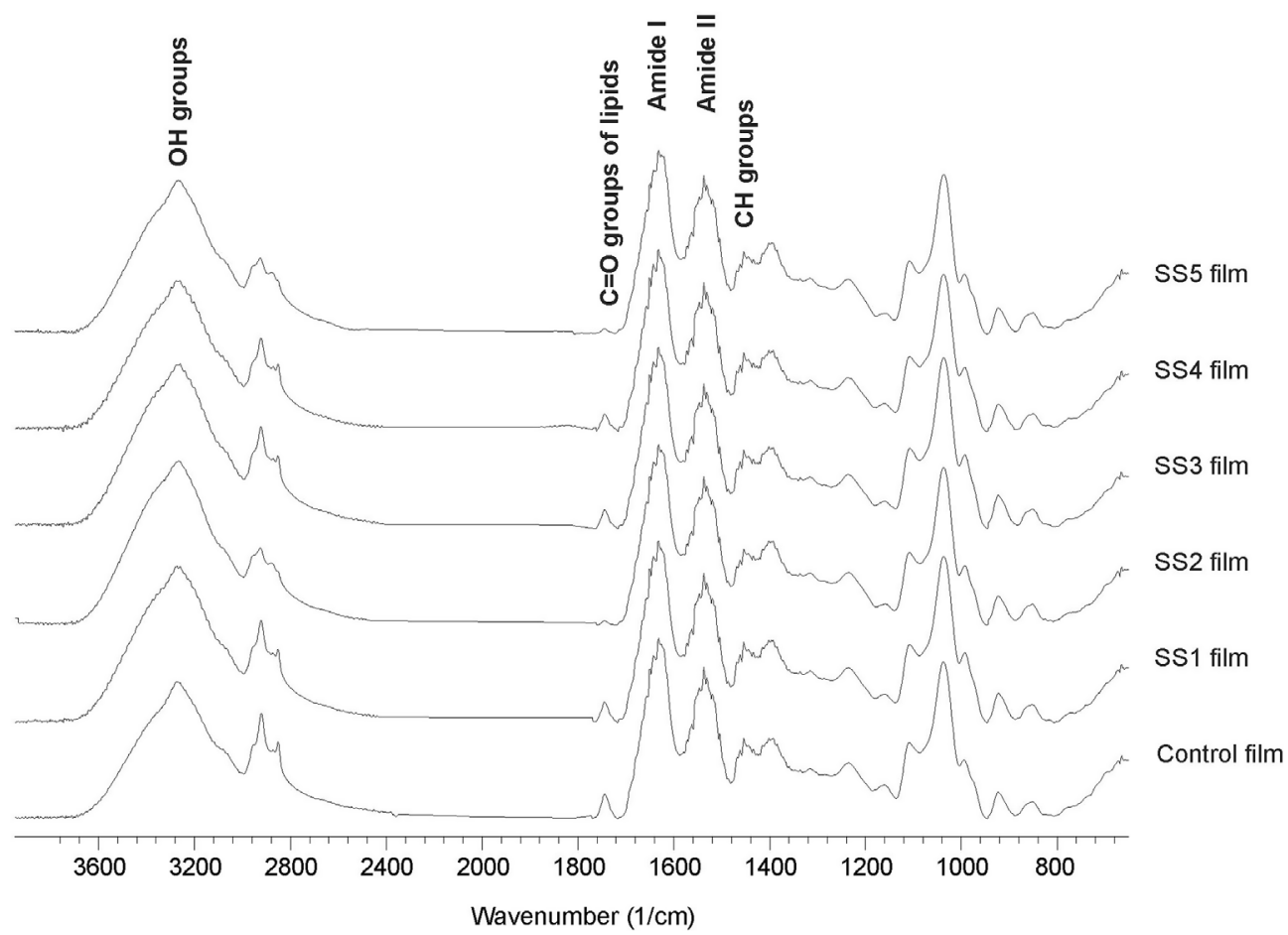

Fig. 2. FTIR absorbance spectra of WPC-based films (control: correspond to films without SS; SS1, SS2, SS3, SS4 and SS5 films: correspond to films incorporated with different SS). 
bond, which is highly influenced by hydrogen bonding and thus to protein secondary structure. The signal associated to amide I band for these samples was centered at $1633 \mathrm{~cm}^{-1}$, being that characteristic of $\beta$-sheet structures of proteins (Farrell, Wickham, Unruh, Qi, \& Hoagland, 2001). The signal at $1540 \mathrm{~cm}^{-1}$ corresponded to amide II (combined $\delta(\mathrm{N}-\mathrm{H})$ and $\nu(\mathrm{C}-\mathrm{N})$ ), contributing to the peptide bond group vibrations of proteins. The signal at approximately $1450 \mathrm{~cm}^{-1}$ corresponds to deformation bending of $\mathrm{CH}$ in the $\mathrm{CH}_{2}$ groups. The band centered at $1393 \mathrm{~cm}^{-1}$ could be related with the stretching of $\mathrm{C}=\mathrm{O}$ in the carboxylic acid side chains of amino acids present in whey protein. The bands observed in control films were almost similar to those in the films formulated with SS. Only the band at $1745 \mathrm{~cm}^{-1}$ in the spectra of the films formulated with SS2 and SS5, showed a lower intensity than the same band in the spectra of the other films, including in the control film spectrum. This band was associated with carbonyl stretching vibration likely caused by carbonyl structures, such as aldehydes or esters. Between the physicochemical analyses that were carried out over the SSs, SS2 and SS5 only had in common the highest titratable acidity comparing with the other sauces. Taking into account that, these sauces incorporated presented a higher content of carboxylic groups, it could be possible that the proportion of hydrogen bonds formed with the carbonyl group of fatty acids of WPC yields a decrease in the intensity of the band at $1745 \mathrm{~cm}^{-1}$ due to the limitation of the vibration of these groups.

\subsubsection{Antioxidant activity of films}

The antioxidant properties of WPC-based edible films added with SS at $5 \%(\mathrm{v} / \mathrm{v})$ were investigated using the ABTS radical cation decolorization assay. Control WPC films had a significant antioxidant activity of $12.2 \pm 0.7 \mu \mathrm{mol}$ of Trolox/g sample (Table 3). These results are related with the fact that whey proteins per se have antioxidant properties (Mann et al., 2015). These properties depend on, among others, the presence of sulphur-containing amino acids in the structures of $\beta$ lactoglobulin and $\alpha$-lactoalbumin, two of the major components of whey. More precisely, $\beta$-lactoglobulin is the source of $\gamma$-glutamylcysteine dipeptide, the precursor of glutathione that possesses strong antioxidant (Mann et al., 2015) properties (Smithers, 2008). The main components of antioxidant peptides are the amino acid residues of histidine, tyrosine, methionine, lysine, and tryptophan, which are also antioxidants in their free form. It is not only the amino acid sequence, but also the spatial configuration of the peptide, that give it its antioxidant properties (Bierzuńska, Cais-Sokolińska, Rudzińska, \& GramzaMichałowska, 2017). The scavenging mechanism of WPC is related to the fact that free radicals can react with the residual free amino $\left(\mathrm{NH}_{2}\right)$ groups of proteins to form stable macromolecule radicals, and the $\mathrm{NH}_{2}$ groups can form ammonium $\left(\mathrm{NH}_{3}{ }^{+}\right)$groups by absorbing a hydrogen ion from the solution (Yen, Yang, \& Mau, 2008).

In the case of WPC-based edible films added with SS1, SS2, SS3 and SS4 the antioxidant activity values were not statistically different from control films (Table 3). In general, the natural antioxidant properties of whey masked any additional improved due to SS incorporation and similar antioxidant activity were observed for all WPC-based films, with the exception of those added with SS5 that exhibited a higher antioxidant activity value $(p<0.05)$. Considering that SS5 possessed the higher titratable acidity (Table 1 ), this improved antioxidant activity observed for the films incorporated with this sauce maybe related with the presence of some organic acids (e.g., citric, lactic and acetic acids) that can also act as antioxidants molecules (Syifaa et al., 2016).

\subsubsection{Assessment of films antibacterial activity in solid media}

The acidic condition of the media ( $\mathrm{pH} \mathrm{5.5)}$ ) for the inhibition zone assay was selected to provide a $\mathrm{pH}$ value similar to those reported for several foods, like cheeses and meats (Pérez et al., 2014), but also considering the $\mathrm{pH}$ at which the films were formulated. All WPC-based edible films incorporated with $5 \%(\mathrm{v} / \mathrm{v})$ SS proved to inhibit bacterial growth at films surface for the three foodborne pathogens evaluated, whereas control films were always non-inhibitory. Noticeably, despite not all SS at $5 \%(\mathrm{v} / \mathrm{v})$ showed bacterial inhibitory activity against $E$. coli, L. monocytogenes, and $S$. Typhimurium in liquid medium regulated at pH 5.5 (Table 2), no evidence of microbial growth over film discs were observed. In addition, no inhibition zone around the film disc was observed in any case. The antibacterial properties of WPC-based edible films incorporated with SS could be related with the presence of organic and phenolic acids, flavonoids or melanoidins (Feng et al., 2015; Kataoka, 2005; Kim et al., 2013). Furthermore, the antibacterial activity might be due to a synergistic effect between various components, whether major or minor ones. When SS are incorporated into WPCbased edible films, the antibacterial components may be retained by strong interaction with the protein backbone, and thus their antimicrobial activity could not be evidenced as an inhibition zone around the film disc due to diffusion restrictions from the film matrix to the surrounding solid media. As we stated in a previous work, carbonyl and phenolic compounds may strongly interact with milk proteins at WPC films (Soazo et al., 2016). In addition, phenolic acids could interact with the structural subunits of $\alpha$-lactoalbumin and $\beta$-lactoglobulin (the two most abundant proteins in milk whey) and, thus altering protein conformation (Zhang, Hsieh, \& Vardhanabhuti, 2014). Therefore, it is feasible that SS bioactive compounds could be retained by the WPCbased matrix of the edible films.

Considering that post-processing surface bacterial contamination is a major issue for the food industry, our results are promising since one of the principal issues to overcome is that bioactive edible films retains the antimicrobial activity once in contact with foods (Pérez et al., 2014). Moreover, it is also important that antibacterial components of antimicrobial edible films do not diffuse to the wrapping food thus altering food composition. This fact is not a minor one since current consumers concerns are related with the presence of food additives and its potential impact on human health (Kostik, 2014). Hence, it is necessary to determine adequate edible film composition to obtain films with a satisfactory antimicrobial activity within the accepted policies for food care and human safety.

\section{Conclusions}

In our study, all WPC-based edible films formulated with the incorporation of SS proved to be transparent and clear enough to be used as see-through packaging. Furthermore, the addition of SS caused that films acquired a distinctive brownish colour. On the other hand, the incorporation of SS at $5 \%(\mathrm{v} / \mathrm{v})$ do not much improved films mechanical resistance, but increased films elongation which is a desired aspect for packaging applications as for example a "home-made" sushi preparations in replace of nori algae (alga use is already questioned for its high iodine content and its potential arsenic content). Interestingly, the incorporation of SS into acidic WPC-based edible films inhibited the superficial growth of the foodborne pathogens E. coli, L. monocytongenes and $S$. Typhimurium, despite the lack of a clear inhibition zone around the film discs in the diffusion agar test. This behaviour could be related with the presence of organic acids or other compounds at SS composition that increase their activity in the non-ionized state. Additionally, all films formulated at the present work showed similar antioxidant properties when SS was incorporated at $5 \% \mathrm{v} / \mathrm{v}$, but this feature was principally related with the WPC backbone. However, the five SS analyzed showed high antioxidant activity in liquid medium that could be associated with the phenolic compounds content, among other substances like isoflavones and melanoidins. Hence, more research is needed to optimized edible films formulations with the incorporation of bioactive additives, such as SS, in order to obtain films with more satisfactory antioxidant and antimicrobial properties within the accepted policies for food care and human health. 


\section{Acknowledgements}

This work was supported by grants from Consejo Nacional de Investigaciones Científicas y Técnicas (CONICET, Argentina), Universidad Nacional de Rosario (UNR, Argentina), and Agencia Nacional de Promoción Científica y Tecnológica (ANPCyT, Argentina).

\section{References}

AOAC (2012). Association of official analytical chemists. Method 942.15. Official methods of analysis of AOAC International (19th ed.). Arlington, VA: AOAC International.

ASTM. (2000). Standard test method for trace quantities of carbonyl compounds with 2,4dinitrophenylhydrazine. Annual book of ASTM standards (pp. 1-3). Philadelphia, PA: ASTM E411-00.

Bahram, S., Rezaei, M., Soltani, M., Kamali, A., Ojagh, S. M., \& Abdollahi, M. (2014). Whey protein concentrate edible film activated with cinnamon essential oil. Journal of Food Processing and Preservation, 38(3), 1251-1258.

Barba, C., Eguinoa, A., \& Maté, J. I. (2015). Preparation and characterization of $\beta$-cyclodextrin inclusion complexes as a tool of a controlled antimicrobial release in whey protein edible films. Lebensmittel-Wissenschaft und -Technologie-Food Science and Technology, 64(2), 1362-1369.

Bayliak, M., Burdyliuk, N. I., \& Lushchak, V. (2016). Effects of pH on antioxidant and prooxidant properties of common medicinal herbs. Open Life Science, 11, 298-307.

Beristain-Bauza, S.d. C., Mani-López, E., Palou, E., \& López-Malo, A. (2017) Antimicrobial activity of whey protein films supplemented with Lactobacillus sakei cell-free supernatant on fresh beef. Food Microbiology, 62, 207-211.

Bessone, A. (2015). Propiedades antimicrobianas de películas comestibles elaboradas a base de concentrado de proteínas del suero de quesería adicionadas con conservantes alimenticios. Rosario: National University of Rosario.

Bierzuńska, P., Cais-Sokolińska, D., Rudzińska, M., \& Gramza-Michałowska, A. (2017). Evaluation of antioxidant activity of whey protein to improve cholesterol oxidation stability in fresh white cheese from buttermilk. Journal of Food and Nutrition Research, 56(2), 101-108.

Boyac1, D., Korel, F., \& Yemenicioğlu, A. (2016). Development of activate-at-home-type edible antimicrobial films: An example $\mathrm{pH}$-triggering mechanism formed for smoked salmon slices using lysozyme in whey protein films. Food Hydrocolloids, 60, 170-178.

Chaturvedula, C. V. S. P., \& Prakash, I. (2011). The aroma, taste, color and bioactive constituents of tea. Journal of Medicinal Plants Research, 5(11), 2110-2124.

Cho, J.-H.,., Zhao, H.-I., Kim, J.-R., Kim, S.-H., \& Chung, C.-H. (2018). Characteristics of fermented seasoning sauces using Tenebrio molitor larvae. Innovative Food Science \& Emerging Technologies, 45, 186-195.

Chun, O. K., Kim, D. O., Smith, N., Schroeder, D., Han, J. T., \& Lee, C. Y. (2005). Daily consumption of phenolics and total antioxidant capacity from fruit and vegetables in the American diet. Journal of the Science of Food and Agriculture, 85(10), 1715-1724.

Yen, M. T., Yang, J. H., \& Mau, J. L. (2008). Antioxidant properties of chitosan from crab shells. Carbohydrate Polymers, 74, 840-844.

Zhang, S., Hsieh, F.-H., \& Vardhanabhuti, B. (2014). Acid-induced gelation properties of heated whey protein-pectin soluble complex (Part I): Effect of initial pH. Food Hydrocolloids, 36, 76-84.

Código Alimentario Argentino. (2018). Chapter XVIII. Aditivos alimentarios. https:// www.argentina.gob.ar/sites/default/files/anmat-capitulo_xviii_aditivosactualiz 2018-11.pdf.

Farrell, H. M., Wickham, E. D., Unruh, J. J., Qi, P. X., \& Hoagland, P. D. (2001) Secondary structural studies of bovine caseins: Temperature dependence of $\beta$-casein structure as analyzed by circular dichroism and FTIR spectroscopy and correlation with micellization. Food Hydrocolloids, 15(4), 341-354.

Feng, Y., Su, G., Zhao, H., Cai, Y., Cui, C., Sun-Waterhouse, D., et al. (2015). Characterisation of aroma profiles of commercial soy sauce by odour activity value and omission test. Food Chemistry, 167, 220-228.

Hamano, M. (1994). Water Activity and Water Behavior of Soy Sauce, Dehydrated Soy Sauce and the Improvement on Hygroscopicity of Dehydrated Soy Sauce. Developments in Food Engineering. Eds In: Yano T., Matsuno R., Nakamura K.. Boston, MA: Springer.

Hemar, Y., Law, A. J. R., Horne, D. S., \& Leaver, J. (2000). Rheological investigations of alkaline-induced gelation of skimmed milk and reconstituted skimmed milk concentrates. Food Hydrocolloids, 14(3), 197-201.

Hernandez-Izquierdo, V. M., \& Krochta, J. M. (2008). Thermoplastic processing of proteins for film formation-a review. Journal of Food Science, 73(2), R30-R39.

Janser Soares de Castro, R., Domingues, M. A. F., Ohara, A., Okuro, P. K., dos Santos, J. G., Brexó, R. P., et al. (2017). Whey protein as a key component in food systems: Physicochemical properties, production technologies and applications. Food Structure, 14, 17-29.

Jiang, Y., Li, Y., Chai, Z., \& Leng, X. (2010). Study of the physical properties of whey protein isolate and gelatin composite films. Journal of Agricultural and Food Chemistry, 58(8), 5100-5108.
Kamal, G. M., Wang, X., Bin, Y., Wang, J., Sun, P., Zhang, X., et al. (2016). Compositional differences among Chinese soy sauce types studied by (13)C NMR spectroscopy coupled with multivariate statistical analysis. Talanta, 158, 89-99.

Kataoka, S. (2005). Functional effects of Japanese style fermented soy sauce (shoyu) and its components. Journal of Bioscience and Bioengineering, 100(3), 227-234.

Kim, H.-W., Choi, Y.-S., Choi, J.-H., Kim, H.-Y., Hwang, K.-E., Song, D.-H., et al. (2013). Antioxidant effects of soy sauce on color stability and lipid oxidation of raw beef patties during cold storage. Meat Science, 95(3), 641-646.

Kostik, V. (2014). A comprehensive study of the presence of some food additives in nonalcoholic beverages in Republic of Macedonia from the period 2008- 2012. Journal of Hygienic Engineering and Design, 7, 124-133.

Li, H., Lin, L., Feng, Y., Zhao, M., Li, X., Zhu, Q., et al. (2018). Enrichment of antioxidant from soy sauce using macroporous resin and identification of 4-ethylguaiacol, catechol, daidzein, and 4-ethylphenol as key small molecule antioxidants in soy sauce. Food Chemistry, 240(Supplement C), 885-892.

Lin, D., \& Zhao, Y. (2007). Innovations in the development and application of edible coatings for fresh and minimally processed fruits and vegetables. Comprehensive Reviews in Food Science and Food Safety, 6(3), 60-75.

Lück, E., \& Jager, M. (1997). Antimicrobial food additives: Characteristics, uses, effects. Springer.

Mann, B., Kumari, A., Kumar, R., Sharma, R., Prajapati, K., Mahboob, S., \& Athira, S. (2015). Antioxidant activity of whey protein hydrolysates in milk beverage system. Journal of Food Science and Technology, 52(6), 3235-3241.

Mellinas, C., Valdés, A., Ramos, M., Burgos, N., Garrigós, M.d. C., \& Jiménez, A. (2016) Active edible films: Current state and future trends. Journal of Applied Polymer Science, 133(2).

Otoni, C. G., Avena-Bustillos, R. J., Azeredo, H. M. C., Lorevice, M. V., Moura, M. R. Mattoso, L. H. C., et al. (2017). Recent advances on edible films based on fruits and vegetables-a review. Comprehensive Reviews in Food Science and Food Safety, 16(5), $1151-1169$.

Pérez, L. M., Piccirilli, G. N., Delorenzi, N. J., \& Verdini, R. A. (2016). Effect of different combinations of glycerol and/or trehalose on physical and structural properties of whey protein concentrate-based edible films. Food Hydrocolloids, 56, 352-359.

Pérez, L. M., Soazo, M.d. V., Balagué, C. E., Rubiolo, A. C., \& Verdini, R. A. (2014). Effect of $\mathrm{pH}$ on the effectiveness of whey protein/glycerol edible films containing potassium sorbate to control non-O157 shiga toxin-producing Escherichia coli in ready-to-eat foods. Food Control, 37, 298-304.

Ramos, Ó. L., Reinas, I., Silva, S. I., Fernandes, J. C., Cerqueira, M. A., Pereira, R. N., et al (2013). Effect of whey protein purity and glycerol content upon physical properties of edible films manufactured therefrom. Food Hydrocolloids, 30(1), 110-122.

Rufián-Henares, J.Á., Guerra-Hernández, E., \& García-Villanova, B. (2013). Effect of red sweet pepper dehydration conditions on Maillard reaction, ascorbic acid and antioxidant activity. Journal of Food Engineering, 118(1), 150-156.

Salgado, P. R., Ortiz, C. M. Musso, Y. S., Di Giorgio, L, \& Mauri, A. N. (2015), Edible films and coatings containing bioactives. Current Opinion in Food Science, 5, 86-92.

Smithers, G. W. (2008). Whey and whey proteins-From "Gutter-to-Gold". International Dairy Journal, 18, 695-704.

Soazo, M., Pérez, L. M., Piccirilli, G. N., Delorenzi, N. J., \& Verdini, R. A. (2016) Antimicrobial and physicochemical characterization of whey protein concentrate edible films incorporated with liquid smoke. Lebensmittel-Wissenschaft und -Technologie- Food Science and Technology, 72, 285-291.

Soazo, M., Pérez, L. M., Rubiolo, A. C., \& Verdini, R. A. (2013). Effect of freezing on physical properties of whey protein emulsion films. Food Hydrocolloids, 31(2) 256-263.

Soazo, M., Pérez, L. M., Rubiolo, A. C., \& Verdini, R. A. (2015). Prefreezing application of whey protein-based edible coating to maintain quality attributes of strawberries. International Journal of Food Science and Technology, 50(3), 605-611.

Soazo, M., Rubiolo, A. C., \& Verdini, R. A. (2011). Effect of drying temperature and beeswax content on physical properties of whey protein emulsion films. Food Hydrocolloids, 25(5), 1251-1255.

Sun, X., Wang, Z., Kadouh, H., \& Zhou, K. (2014). The antimicrobial, mechanical, physical and structural properties of chitosan-gallic acid films. Lebensmittel-Wissenschaft und -Technologie- Food Science and Technology, 57(1), 83-89.

Syifaa, A. S., Jinap, S., Sanny, M., \& Khatib, A. (2016). Chemical profiling of different types of soy sauce and the relationship with its sensory attributes. Journal of Food Quality, 39(6), 714-725.

Wang, B., Huang, Q., Venkitasamy, C., Chai, H., \& Pan, Z. (2016). Changes in phenolic compounds and their antioxidant capacities in jujube (Ziziphus jujuba Miller) during three edible maturity stages. LWT - Food Science and Technology, 66, 56-62

Wijayanti, H. B., Bansal, N., \& Deeth, H. C. (2014). Stability of whey proteins during thermal processing: A review. Comprehensive Reviews in Food Science and Food Safety, 13, 1235-1251.

Xu, D., Li, C., Zhao, M., Fengc, Y., Sun, L., \& Wang, Y. (2013). Assessment on the improvement of soy sauce fermentation by Aspergillus oryzae HG76. Biocatalysis and Agricultural Biotechnology, 2(4), 344-351. 